\title{
PENANGGULANGAN KEMISKINAN MELALUI PROGRAM NASIONAL PEMBERDAYAAN MASYARAKAT (PNPM) MANDIRI PERDESAAN
}

\section{POVERTY THROUGH NATIONAL EMPOWERMENT PROGRAM (PNPM) MANDIRI RURAL AREAS}

\author{
Prabawa Eka Soesanta \\ Kepala Bagian Perencanaan pada \\ Badan Penelitian dan Pengembangan (BPP) - Kementerian Dalam Negeri \\ J1. Kramat Raya No. 132 - Senen, Jakarta \\ Dikirim: 14 Maret 2013; direvisi: 25 April 2013; disetujui: 19 Juni 2013
}

\begin{abstract}
Abstrak
Tulisan ini bertujuan untuk memahami konsep dan pelaksanaan PNPM Mandiri Perdesaan dalam penanggulangan kemiskinan sebagai model pembangunan di Indonesia. Kondisi ini memerlukan solusi yang terintegrasi terkait pola adhoc yang ada di PNPM Mandiri Perdesaan, sehingga berbicara sustainabilitas aakan menjadi sulit jika tidak disusun formula yang tepat. Tulisan ini juga mengkaji beberapa hal yang terjadi mulai dari sejarah program-program penanggulangan kemiskinan di Indonesia, sampai munculnya prioritas program nasional dibawah PNPM Mandiri (Perdesaan dan Perkotaan). Hal lain yang dikaji dalam tulisan ini adalah capaian yang selama ini diperoleh dalam pelaksanaan PNPM Mandiri Perdesaan. Akan tetapi keberhasilan pelaksanaan PNPM Mandiri Perdesaan, agar dapat dilanjutkan maka perlu diperbaiki baik dari kelembagaan/struktur masyarakat; prosedur yang ada, maupun budaya yang ada di PNPM Mandiri Perdesaan. Perbaikan itu merupakan upaya untuk menyempurnakan program pemberdayaan masyarakat dengan pendekatan partisipatif.

Kata kunci: Pemberdayaan, partisipasi, dan kemiskinan.
\end{abstract}

\begin{abstract}
This paper aims to understand the concept and implementation of PNPM Rural poverty reduction as a model of development in Indonesia. This condition requires a solution that integrates existing adhoc related patterns in PNPM Rural, so that sustainability will be difficult if not prepared right formula. This paper also examines some of the things that occurred starting from the history of poverty alleviation programs in Indonesia, until the emergence of a national program priorities under the PNPM Mandiri (Rural and Urban). Another thing that is studied in this paper is the achievements that have been obtained in the implementation of PNPM Rural. However, the successful implementation of PNPM Rural, in order to continue it needs to be improved both from the institutional /community structures existing procedures, and culture in PNPM. Improvements was an attempt to enhance community development program with a participatory approach.
\end{abstract}

Keywords: empowerment, participation, and poverty.

\section{PENDAHULUAN}

Menjelang peringatan hari kemerdekaan yang ke-68, merefleksikan kembali merenungkan kembali akan apa yang cita-cita berdirinya Negara Indonesia sesuai dengan Pembukaan UUD 1945 sangat diperlukan. Hal ini untuk melihat perjalanan bangsa Indonesia dalam mencapai kesejahsejahteraan masyarakat Indonesia sesuai tujuan utama bagi NKRI. Disamping upaya untuk mencapai kesejateraan masyarakat maka upaya untuk mengatasi kemiskinan merupakan salah satu tujuan yang menjadi kesepakatan Indonesia sebagai bentuk komitmen internasional yang tertuang dalam Millennium Development Goals (MDGs).
Terkait dengan situasi di atas maka upaya meningkatkan kesejahteraan masyarakat, persoalan kemiskinan menjadi problem sosial secara bertahap mulai dapat terpecahkan secara sistematis. Dari hasil data BPS periode Maret 2012-September 2012, persentase penduduk miskin di daerah perkotaan dan perdesaan tercatat mengalami penurunan. Persentase penduduk miskin di daerah perkotaan pada Maret 2012 sebesar 8,78 persen, turun menjadi 8,60 persen pada September 2012. Sementara penduduk miskin di daerah perdesaan menurun dari 15,12 persen pada Maret 2012 menjadi 14,70 persen pada September 2012. 


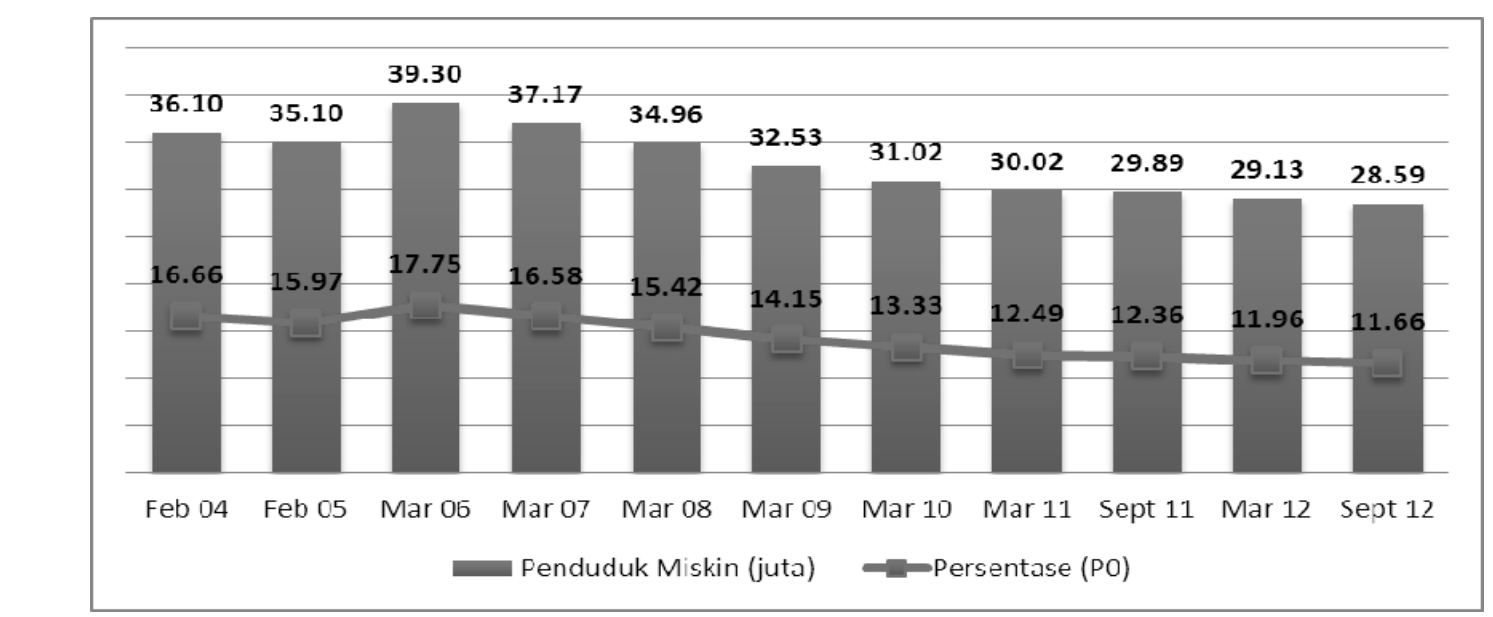

Sumber: Data BPS 2013

Untuk menanggulangi kemiskinan yang terjadi Pemerintah telah melakukan berbagai kebijakan dan program yang bertujuan untuk menanggulangi kemiskinan. Kebijakan penanggulangan kemiskinan atau dengan nama lain, mulai aktif dijalankan sejak tahun 1974 sampai sekarang. Pada awalnya program peningkatan kesejahteraan masyarakat dimulai dari sektor pertanian, dan transmigrasi, dan berbagai program lain seperti Binmas, Inmas, Koperasi, Inpres dan lain sebagainya. Akan tetapi, apa yang menjadi program pembangunan yang dijalankan secara masif menjadi sangat sentralistis dan bersifat top down. Kebijakan pembangunan yang pada saat itu menjadikan pertumbuhan ekonomi menjadi prioritas menjadikan berbagai program untuk meningkatkan kesejahteraan masyarakat hanya sebagai pelengkap untuk mengatasi dampak pembangunan yang terjadi. Hal ini menjadikan banyaknya program untuk masyarakat sejak 1992 melalui IDT, KUBE, dan sebagainya bukan menjadikan kesejahteraan masyarakat meningkat tetapi ketergantungan terhadap pemerintah semakin tinggi

Ketika krisis ekonomi dan politik tahun 1998, Pemerintah meluncurkan Program Pengembangan Kecamatan (PPK) dan pada tahun berikutnya diluncurkan Program Pengembangan Kawasan Perkotaan (P2KP). Kedua program ini merupakan cikal bakal lahirnya program prioritas nasional dalam rangka penanggulangan kemiskinan yaitu: PNPM Mandiri yang dikukuhkan pada tanggal oleh Presiden RI di Kota Palu, 30 April 2007. Dalam rangka memperkuat PNPM Mandiri sebagai program prioritas nasional dikeluarkanPeraturan Presiden (Perpres) Nomor 10 tentang Percepatan Penanggulangan Kemiskinan, menetapkan 3 (tiga) kelompok program penanggulangan kemiskinan sebagai instrument percepatan penanggulangan kemiskinan nasional. yaitu: kluster pertama bantuan dan perlindungan sosial, kluster kedua pemberdayaan masyarakat dan kluster ketiga Kredit
Usaha Rakyat, dan dilakukan penambahan kluster IV tentang peningkatkan dan perluasan program pro rakyat.

Dengan melihat situasi tersebut, menjadikan PNPM Mandiri Perdesaan menjadi satu-satunya program penanggulangan kemiskinan terbesar di dunia, terutama dari jumlah lokasi yang ada. Pada tahun 2013 tersebar di 32 provinsi, 393 kabupaten, dan 5.146 kecamatan. Dengan begitu besarnya program maka karakter pemberdayaan akan menjadi berkurang dan lebih fokus pada urusan pengendalian program. Disamping itu, PNPM Mandiri Perdesaan berperan sebagai penyelesaian akan segala permasalahan pembangunan yang berdamak pada kemiskinan. Untuk itu, mencari formula terhadap penanggulangan kemiskinan melalui pemberdayaan masyarakat sangat diperlukan sehingga, orientasi keproyekan dapat teratasi ketika pembangunan itu sendiri sudah mengcover dampak dari kemiskinan. Hal lain yang perlu menjadi perhatian adalah ketika PNPM Mandiri Perdesaan menjadi program masal maka arah pemberdayaan akan tetap ada, atau lebih bersifat mekanis keproyekan? Kedua hal tersebut yang menjadi kajian dalam pembahasan tentang penanggulangan kemiskinan melalui PNPM Mandiri Perdesaan.

\section{PEMBAHASAN}

\section{Capaian PNPM Mandiri Perdesaan}

Pelaksanaan PNPM Mandiri Perdesaan 2007 2012 terdapat beberapa capaian yang berdampak pada : 1) peningkatan konsumsi per kapita 5\% lebih tinggi pada rumahtangga di daerah treatment dibandingkan dengan daerah kontrol; 2) rumah tangga miskin yang mendapat PNPM Perdesaan meningkat konsumsinya sebesar 3\% lebih besar dan memiliki kemungkinan keluar dari kemiskinan 2,3\% lebih besar jika dibandingkan dengan rumah tangga miskin di daerah kontrol; dan 3) rumah tangga 
kelompok treatment jugamemiliki kesempatan lebih tinggi untuk mendapatkan pekerjaan dan akses pelayanan kesehatan.Namun berbagai manfaat tersebut dampaknya sangat kecil dirasakan oleh rumah tangga rentan seperti rumah tangga yang dikepalai perempuan atau kepala rumah tangganya tidak berpendidikan.

Dari hasil capaian tersebut menunjukkan, biaya yang dikeluarkan untuk pelaksanaan PNPM Mandiri Perdesaan maupun hasil kegiatan dari PNPM Mandiri Perdesaanmemiliki faktor efisiensi yang tinggi. Hal ini terlihat dari adanya peluang kesempatan kerja, membaiknya infrastruktur dan produktivitas ekonomi di desa. Tingginya kegiatan infrastruktur dalam PNPM Mandiri Perdesaan, disebabkan oleh kurangnya infrastruktur di desa dan PNPM Mandiri Perdesaandianggap dapat menetralisir dampak negatif program bersasaran rumah tangga seperti BLT, Raskin, PKH, dan Jamkesmas.

Berikut ini tabel lokasi dan alokasi dana Bantuan Langsung Masyarakat yang disalurkan melalui PNPM Mandiri Perdesaan.

Disamping itu, dari mekanisme penyaluran dana pembangunan dari pusat ke desa, PNPM Mandiri Perdesaan sangat efektif dan efisien, namun dari sisi pemberdayaan masih perlu perbaikan. Upaya penting yang diperlukan antara lain adalah mengintegrasikan musyawarah perencanaan PNPMMandiri Perdesaan dengan Musrenbangdes sehingga aspirasi warga yang tidak tertampung di PNPM Mandiri Perdesaan dapat tetap direalisasikan.Dalam konteks upaya penanggulangan kemiskinan, hasil-hasil yang dicapai melalui PNPM Mandiri dibutuhkan perubahan paradigma pembangunan dari top down menjadi bottom up, dengan memberi peran masyarakat sebagai aktor utama atau subyek pembangunan sedangkan pemerintah sebagai fasilitator. Proses bottom up akan memberi ruang bagi masyarakat desa untuk berpartisipasi dalam merencanakan, menentukan kebutuhan, mengambil keputusan, melaksanakan, hingga mengevaluasi pembangunan.Korten (1993) menyatakan konsep pembangunan berpusat pada rakyat memandang inisiatif kreatif dari rakyat sebagai sumber daya pembangunan yang utama dan memandang kesejahteraan material dan spiritual mereka sebagai tujuan yang ingin dicapai oleh proses pembangunan.

Konsep yang menempatkan kemiskinan dibagi dalam dua jenis, juga disampaikan Suwondo (1982) bahwa kemiskinan terbagai menjadi kemiskinan mutlak (absolute proverty) yaitu: individu atau kelompok yang tidak dapat memenuhi kebutuhan dasarnya, bahkan kebutuhan fisik minimumnya, dan kemiskinan relatif (relative proverty) yaitu menekankan ketidaksamaan kesempatan dan kemampuan diantara lapisan masyarakat untuk mendapatkan barang-barang dan pelayanan dalam menikmati kehidupannya. Pengertian kemiskinan yang lebih luas disampaikan oleh John Friedman (Ala, 1996) yang menyatakan bahwa kemiskinan sebagai ketidaksamaan untuk mengakumulasikan basis kekuasaaan sosial, yaitu kemampuan untuk menguasai peluang strategis yang bisa mempengaruhi kehidupan sosial, ekonomi, dan politik.

Mengembangkan pendekatan pemberdayaan masyarakat akan meningkatkan efektifitas dan efesiensi penggunaan sumber daya pembangunan yang makin langka. Program-program pemerintah yang berbasis pemberdayaan seperti PNPM Mandiri Perdesaan telah memberi banyak pengalaman dalam menekan biaya untuk suatu pekerjaan dengan kualitas yang sama yang dikerjakan program non pemberdayaan. Pendekatan ini akan meningkatkan relevansi program pembangunan (pemerintah) terhadap masyarakat lokal dan meningkatkan kesinambungannya, dengan mendorong rasa memiliki dan tanggung jawab masyarakat.

Pemberdayaan masyarakat adalah sebuah konsep pembangunan ekonomi yang merangkum nilai-nilai sosial. Konsep ini mencerminkan paradigma baru pembangunan, yakni yang bersifat "people-centered, participatory, empowering, and sustainable" (Chambers, 1995). Konsep ini lebih luas dari hanya semata-mata memenuhi kebutuhan dasar (basic needs) atau menyediakan mekanisme untuk mencegah proses pemiskinan lebih lanjut (safety net), yang pemikirannya belakangan ini banyak

Tabel 1. Lokasi dan alokasi

PNPM Mandiri Perdesaan 2007 - 2013

\begin{tabular}{|c|c|c|c|c|c|c|c|}
\hline \multirow{2}{*}{$\begin{array}{c}\text { Level } \\
\text { Pemerintahan }\end{array}$} & \multicolumn{7}{|c|}{ Cakupan Wilayah } \\
\hline & 2007 & 2008 & 2009 & 2010 & 2011 & 2012 & 2013 \\
\hline Provinsi & 32 & 32 & 32 & 32 & 32 & 32 & 32 \\
\hline Kabupaten & 346 & 366 & 364 & 393 & & 393 & 393 \\
\hline Kecamatan & 1.993 & 2.835 & 4.334 & 4791 & 4911 & 5.102 & 4.791 \\
\hline Desa & 29.869 & 40.784 & 57.266 & 57.339 & 68.807 & 72.247 & 74.415 \\
\hline Total BLM (jt) & 1.961 .750 & 4.347 .343 & 6.478 .550 & 7.257 .750 & 8.440 .156 & 8.561 .709 & 8.621 .640 \\
\hline
\end{tabular}

Sumber: Sekretariat PNPM Mandiri Perdesaan, Ditjen PMD 
dikembangkan sebagai upaya mencari alternatif terhadap konsep-konsep pertumbuhan di masa yang lalu. Konsep ini berkembang dari upaya banyak ahli dan praktisi untuk mencari apa yang antara lain oleh Friedman (1992) disebut alternative development yang menghendaki "inclusive democracy, appropriate economic growth, gender equality and intergenerationalequity”.

Dalam konteks upaya penanggulangan kemiskinan, maka apa yang dilakukan melalu PNPM Mandiri Perdesaan merupakan dobrakan terhadap sistem yang selama ini tidak berpihak pada masyarakat desa. Perubahan paradigma pembangunan daritop down menjadi bottom up, dengan memberi peran masyarakat sebagai aktor utama atau subyek pembangunan sedangkan pemerintah sebagai fasilitator. Proses bottom up akan memberi ruang bagi masyarakat desa untuk berpartisipasi dalam merencanakan, menentukan kebutuhan, mengambil keputusan, melaksanakan, hingga mengevaluasi pembangunan.

\section{Pengalaman Pelaksanaan PNPM Mandiri Perdesaan}

Dari pelaksanaan PNPM Mandiri Perdesaan selama ini, terdapat beberapa keunggulan pelaksanaan yang didapat seperti:

\section{Pendekatan pemberdayaan masyarakat}

Masyarakat tidak hanya menjadi penerima manfaat namun diposisikan sebagai subyek atau pelaku utama pembangunan. Masyarakat dilatih dan diorganisir sedemikian hingga dapat mengartikulasikan aspirasinya dalam merencanakan, membuat prioritas, mengambil keputusan, dan melaksanakan pembangunan. Melalui pendekatan ini, masyarakat diharapkan memiliki kemauan dan kemampuan untuk menolong dirinya sendiri. Berbeda dengan charity yang memberikan bantuan jangka pendek, pemberderdayaan ditujukan untuk meningkatkan kapasitas masyarakat dalam melakukan pembangunan jangka panjang secara berkelanjutan. Kondisi ini menjaikan PNPM Mandiri Perdesaan menjadi rujukan/percontohan dari berbagai negara yang mecoba menerapakan pola PNPM Mandiri Perdesaan di negara-negara berkembang, Asia, maupun Afrika.

2. Transparan dan akuntabel

PNPM Mandiri Perdesaan telah menjadi media belajar bagi setiap pihak tentang transparansi dalam mengelola dana-dana pembangunan untuk masyarakat. Ada banyak pihak yang dilibatkan dalam mengawasi program mulai dari internal proyek seperti konsultan dan Tim koordinasi ampai eksternal proyek seperti dari LSM, wartawan, auditor BPK, BPKP, dan sebagainya. Meskipun hingga saat ini masih terdapat masalah penyalahgunaan dana dalam jumlah besar, namun jumlah ini relatif kecil bila dibandingkan dengan total dana PNPM Mandiri Perdesaan atau bila dibandingkan dengan kebocoran pada proyek-proyek pemerintah lainnya.

3. Dalam menjaga prinsip transparansi dan akuntabilitas, PNPM Mandiri Perdesaan bahkan telah mengorganisir dan melatih masyarakat untuk berperan langsung dalam memonitor atau mengawasi program. PNPM Mandiri Perdesaan juga berupaya mengembangkan audit antardesa.

4. Open menu

Kegiatan-kegiatan dalam PNPM Mandiri Perdesaan sangat beragam disesuaikan dengan pilihan kebutuhan masyarakat. Masyarakat diberi kesempatan untuk memilih kegiatan mana yang sesuai kebutuhannya. Pilihan tersebut diantaranya adalah kegiatan infrastruktur/ sarana fisik, usaha ekonomi produktif, simpan pinjam kelompok perempuan, kegiatan bidang pendidikan dan kesehatan. Masyarakat difasilitasi untuk menemukenali kebutuhannya, menyusun prioritas, dan membuat usulan kegiatan di tingkat desa dan kecamatan. Keputusan pembiayaan kegiatan yang terpilih diambil berdasarkan musyawarah antar desa yang merupakan forum tertinggi di PPK.

5. Pendekatan keruangan berbasis kecamatan Skema pemberdayaan dan penyaluran Bantuan Langsung Masyarakat PNPM Mandiri Perdesaan mengambil basis masyarakat di tingkat kecamatan. Dengan menempatkan kecamatan sebagai basis pemberdayaan dan kompetisi BLM, penyaluran bantuan dan pelaksanaan skema program akan berjalan secara efektif. Dengan adanya BLM di tingkat kecamatan maka pembangunan dengan mengutamakan kepentingan masyarakat antar desa dan kewilayahan dapat teratasi.

6. Melibatkan banyak stakeholder

Dalam pelaksanaannya, banyak pihak belajar dari PNPM Mandiri Perdesaan mengenai model pembangunan partisipatif. Pelaksanaan PPK melibatkan banyak stakeholder mulai dari masyarakat, pemda, LSM, perguruan tinggi, wartawan, bahkan membuka peluang keterlibatan private sektor didalamnya. Para stakeholder tersebut terlibat dengan peran yang berbeda-beda mulai dari subyek utama, fasilitator, monitoring, auditor, hingga tim studi. Disamping itu, penguatan kapasitas masyarakat juga disalurkan melalui kegiatan Ruang Belajar Masyarakat (RBM). RBM merupakan forum lintas pelaku yang memberi ruang terbuka bagi segenap pihak untuk berdialog, beraktifitas sesuai dengan kondisi yang ada di masing-masing daerah. 


\section{Peran Fasilitator}

Pemberdayaan masyarakat sangat memerlukan peran fasilitator dalam pelaksanaan program. PNPM Mandiri Perdesaan telah merekrut sarjana untuk bekerja mulai dari level kecamatan sampai pusat lebih dari 13.000 orang. Para fasilitator merupakan ahli-ahli pemberdayaan baik terspesilisasi dalam kegiatan sosial, fisik, maupun teknik yang terhimpun dalam beberapa ikatan atau asosiasi pemberdayaan masyarakat. Dalam rangka memberikan pendampingan yang betul-betul kepada masyarakat maka saat ini sedang dipersiapkan sertifikasi bagi para fasilitator PNPM Mandiri Perdesaan.

Dari pelaksanaan PNPM Mandiri Perdesaan selama ini, juga terdapat beberapa kekurangan yang ada seperti:

1. Kelembagaan di PNPM Mandiri Perdesaan masih bersifat adhoc, sehingga nuasa keproyekan susah terintegrasi. Hal ini berdampak pada sustainaibilitas kelembagaan kedepan.

2. Terkait kegiatan simpan pinjam yang ada di PNPM Mandiri Perdesaan, masih besarnya dana mengendap yang tidak digulirkan oleh pengurus UPK.

3. Terlalu luasnya cakupan program, menjadikan PNPM Mandiri Perdesaan belum fokus terhadap apa yang akan dicapai atau prioritas yang akan menjadi arah dan tujuan yang diharapkan.

4. PPK sebagai cikal bakal PNPM Mandiri Perdesaan lahir dari kondisi yang menyimpang pada saat itu. Hal ini tentu tidak sesuai dengan ketentuan maupun regulasi yang seharusnya ada, baik dari sisi perencanaan, implemtasi, maupun evauasi. Ketika hal ini akan dikembalikan kepada sistem regualasi yang ada, maka banyak ketentuan yang tidak sesuai dengan PNPM Mandiri Perdesaan.

\section{SIMPULAN}

a. Dari hasil analisa dapat disimpulkan bahwa pelaksanaan PNPM Mandiri Perdesaan perlu untuk dilanjutkan paska 2014, dengan pertimbangan sebagai berikut:

- PNPM Mandiri dapat menjawab kebutuhan masyarakat terhadap kegiatan yang sudah dimusyawarahkan. Hal ini merupakan bentuk demokrasi dileberatif yang secara riil dipraktekan diseluruh lokasi PNPM mandiri Perdesaan

- Disamping itu, PNPM Mandiri Perdesaan terbukti dapat memberikan pendelegasian yang jelas kepada masyarakat mulai dari perencanaan sampai dengan evaluasi kegiatan. b. Disamping itu, ada beberapa kendala yang perlu diperbaiki dalam pelaksanaan PNPM Mandiri Perdesaan ke depan baik dari sisi kelembagaan/struktur; prosedur yang dijalankan, maupun kultur/budaya.

- Kelembagaan/struktur yang ada di PNPM Mandiri Perdesaan masih bersifat adhoc, hal ini tentu menjadi tantangan ketika para pelaku berupaya untuk mengintegrasikan dalam sistem regular. Sebagai contoh: kegiatan SPP yangada di UPK, maka perlu ada perlindungan terhadap asset berguliran yang ada, baik melalui BUMDes ataupun nama lain.

- Prosedur yang ada di PNPM Mandiri Perdesaan dikenal sangat berjenjang dan sisi administrasi lebih ditekankan. Karakter ini terbawa pada para fasilitator yang bekerja di PNPM Mandiri Perdesaan lebih banyak menangani sisi adminitrasi dibandingkan pendampingan kemasyarakat yang membutuhkan inovasi dan kreatifitas. Untuk itu, penyerderhanaan prosedur dan peran pendampingan yang lebih inovatif dan menjadikan pencerahan pada masyarakat sangat diperlukan.

- $\quad$ Budaya di PNPM Mandiri Perdesaan yang sangat taat dengan petunjuk ataupun ketentuan yang ada berdampak pada ketidakberanian maupun keengganan dari para pelaku untuk bertindak lebih. Budaya yang demikian dalam pemberdayaan seharusnya lebih mengarah pada pendekatan kemanusiaan bukan pendekatan administrasi.

- Sistem pendanaan yang menggunakan akun Bantuan Sosial menjadikan pertanggungjawaban terhadap penggunaan dana tersebut menjadi multitafsir, dari pihak pelaksana maupun pemeriksa.

c. Terkait dengan kendala yang ada maka perlu ada upaya perubahan regulasi menyangkut Undang-undang Nomor 32 dan 33 tahun 2004, Undang-undang Nomor 25 tahun 2004, Undang-undang Nomor 17 tahun 2003 beserta turunannya. Perubahan tersebut dimaksudkan untuk menghindarkan pola yang ada di PNPM Mandiri Perdesaan, tertutama pemberian block grant ke desa tidak menjadi perdebatan baik dari perencanaan, pendelegasian kewenangan, sisi pertanggungawajaban keuangan, maupun keberlestarian hasil-hasil kegiatan.

\section{DAFTAR PUSTAKA}

Ala, Andro Bayo, 1996. Kemiskinan dan Strategi Memerangi Kemiskinan, Yogyakarta, Liberty.

Arief, Saeful, 2000. Menolak Pembangunanisme, Yogyakarta, Pustaka Pelajar. 
Chambers, Robert. Poverty and Livelihoods: Whose Reality Counts? Uner Kirdar dan Leonard Silk(eds.), People: From Impoverishment to Empowerment. New York: New York UniversityPress, 1995.

Friedman, John, Empowerment: The Politics of Alternative Development. Cambridge: Blackwell,1992.

Korten, D.C. 1993. Menuju Abad ke-21 : Tindakan Sukarela dan Agenda Global Forum Pembangunan Berpusat-Rakyat. Jakarta : Yayasan Obor Indonesia dan Pustaka Sinar Harapan.

Sumardjan, Selo, 1980. Kemiskinan Struktural dan Pembangunan Kata Pengantar dalam Alfian (at. Al), Kemiskinan Struktural, Suatu Bunga Rampai, Jakarta, YIIS.

Suwondo, Kutut, 1998. Struktur Sosial dan Kemiskinan, Salatiga, Yayasan Bina Dharma.

Salim, Emil, 1984. Perencanaan Pembangunan dan Pemerataan Pendapatan, Jakarta, Inti Idayu Press.

Soetrino, R, 2001. Pemberdayaan Masyarakat dan Upaya Pembebasan Kemiskinan, Yogyakarta, Kanisius. 